\title{
Adolescence Student Behavioral Engagement In Mathematics Class
}

\author{
Dylmoon Hidayat ${ }^{1}$, Tina Kim ${ }^{2}$, Tanti Listiani ${ }^{2}$, Agustina Reni Setianingsih ${ }^{3}$ \\ ${ }^{1}$ Pendidikan Matematika, Universitas Pelita Harapan, Tangerang, Indonesia \\ 2Pendidikan Guru Sekolah Dasar, Universitas Pelita Harapan, Tangerang, Indonesia \\ ${ }^{3}$ Sekolah Dian Harapan, Indonesia \\ e-mail: dylmoon.hidayat@uph.edu
}

\begin{abstract}
Mathematics becomes one of many subjects that shows low student engagement. This paper aims to understand students' attitudes toward school and mathematics, the impact of student behavioral engagement, influential factors, obstacles in promoting student behavioral engagement, and how to promote student behavioral engagement. The results show that students' interests in school decrease in high school. Besides, behavioral engagement impacts academic achievement, the meaning of learning, and self-esteem. Influential factors of student behavioral engagement are motivation, the role of parents and teachers, and peer support. Obstacles in promoting student behavioral engagement are building intrinsic motivation, teachers' beliefs about student behavioral engagement, and parental styles. Some ways to promote student behavioral engagement are using various teaching methods, keeping an optimal learning environment, and focusing on the peer. Conclusion and suggestion emphasize on the role of teachers in their authority in the class and cooperate with parents.
\end{abstract}

Keywords: Behavioral Engagement; Adolescence; Academic Achievement

\section{Introduction}

Education is one of the sectors that the government has high concerned. Many countries try to develop their educational systems. The educational sector, especially for developing countries, is a sector that can determine the future of the nations. One of those countries is Indonesia. One of the efforts to develop education quality is by increasing the state budget. In Indonesia, the data from the Indonesia Financial Ministry 2014 shows that the state budget for the educational sector is increased every year from 2011 to 2014 (Ashari, 2014). This budget is distributed to schools, educational organizations, and educational research around Indonesia. The concern is not merely about increasing the budget, but also making compulsory education for nine years, from elementary school to junior high school. At the end of the academic year, the Senior Grade of these schools should enroll in the national examination. Clark (2014) explains that in the $6^{\text {th }}$ grader of elementary school have Mathematics, Bahasa Indonesia, and science. The 9 graders of junior high school have Mathematics, Bahasa Indonesia, science, and English. Meanwhile, for the grade 12 students of Senior high School, the national exam is divided based on their category, either Natural Science, Social science, or Language. Each of those categories always includes Math, Bahasa, and English, with addition to some tests characterizing each category. Those facts show that Mathematics is one of the required subjects from elementary to secondary. Even in universities, most students have courses related to math, such as Mathematics Essential and Statistics. It means that students study Maths for at least 12 years in school. It is not a short time for learning a subject that most people abominate (Barkatsas, Kasimatis, and Gialamas, 2009).

Students' aversion and other factors affect how they participate in mathematics class (White, 2011). It is also proved that student engagement has become an issue in education. Ideally, Mathematics should be an engaging subject, since, in Math, people learn about finding a solution to problems. Students do not find such an enjoyable moment when they are in math class. Problem-solving is an implicit goal of mathematics. A discovery approach that is at the foundation of "constructivist" activities is built into it. Thus math is a fundamentally engaging subject or should be in a similar way as science is (Shernoff, 2013). 
Each teacher expects to have a working-class which has an optimal learning environment. In an optimal learning environment, there should be an interaction between teachers and students. This interaction is where the teacher is not the only one who delivers the information in the class, and students are the ones who receive the information. Effective communication is built by two-way interaction, meaning that both teachers and students are actively involved in the teaching and learning process (Ketonen and Hotulainen, 2019).

The fact that many types of research investigate student engagement shows its importance in education, for example, participation in a working group (DePree, 1998). The number of researches regarding student engagement also showed that the education experts look at how important it is in the teaching and learning process. Generally, there are three types of student engagement. They are behavioral engagement, cognitive engagement, and emotional engagement. One of the most popular engagement is behavioral engagement. Among the other student engagement, student behavioral engagement is said to be the one that is strongly related to student participation, effort, and actual conduct. Student behavioral engagement problems might lead students to more severe learning problems if it is not handled correctly (Zhu et al., 2019).

Ideally, a class is a pleasant place where students have the willingness to learn and enjoy the class. In a mathematics class, students are supposed to be actively engaged because in mathematics, the concept of discovery and constructing knowledge become the fundamental concept. However, many students are found to be disengaged in mathematics class. Moreover, some of the students admitted that they only concentrate $60 \%$ of the time in class (Macklem, 2015). The role of teachers, here, is significant. As a facilitator, teachers need to help student and accommodate their needs in the classroom (Van Brummelen, 2009). The teacher has an essential role in promoting student behavioral engagement.

This literature review analyzes the adolescents' attitudes towards school and mathematics, the impact of student behavioral engagement, influential factors of student behavioral engagement, obstacles in the effort of promoting student behavioral engagement, and how to promote student behavioral engagement. The review is done by analyzing and comparing researches founded by educators.

\subsection{Behavioral Engagement}

Behavioral engagement is one of three dimensions in student engagement that based on observational measures of how student interested in school task, consistency of effort, participation, attendance, or ethical behavior (Shernoff, 2013). The engagement also has an idealized structure, hypothetical construct, analogous in many ways to cognitive structure. It describes complex "at the moment" affective and social interaction as student work on conceptually challenging mathematics (Goldin, Epstein, Schor, Warmer, 2011)

Based on Conner (2016), behavioral engagement can be divided into positive conduct, involvement in learning and academic tasks, and participation in school-related activities. Actual conduct can be shown by obeying the school rules, attendance in the class, adhering to norms, and avoiding disruptive behaviors. Involvement in learning and academic tasks, for example, student's effort, persistence, attention, participation in class, asking the question, conversing with the teacher and other students. Moreover, participation in school-related activity can be clubs, sports, and school governance. Fredricks, Blumenfeld, \& Paris (2014) found out that although much has been learned, the potential contribution of the concept of school engagement to research on student experience has yet to be realized. They call for more vibrant characterizations of how students behave, feel, and think-research that could aid in the development of finely tuned interventions.

Fredricks et al. (2004) as cited in Hart, Stewart, \& Jimerson (2011, p. 68) said that "behavioral engagement includes observable student actions or participation while at school and is investigated through a student's positive conduct, effort, and participation (e.g., participation in extracurricular activities, attendance, and work habits."

Based on those definitions, it can be said that behavioral engagement is one dimension of student engagement where students show some observable actions, such as actual conduct, effort, participation, and involvement in school. 


\subsection{Adolescence}

Rice \& Dolgin (2008) state that "The word adolescence comes from the Latin verb adolesce, which means "to grow" or "to grow to maturity" ( p. 2). It is the period of growth between childhood and adulthood that everyone must pass before they become mature adults. The time for each person is different from one another, and the transition is gradual and uncertain. Frenzel, Goetz, Pekrun, \& Watt (2010) state that family values and classroom characteristics are positively related to within-person levels of mathematics interest over time and to average individual levels of interest, but not to growth parameters.

Berk (2012) states that adolescence is a transition from childhood to adulthood, which started by puberty. This process includes development to build a relationship with peers and different gender, and also the formation of identity. Santrock (2007, p. 17) states that "adolescence is the developmental period of transition from childhood to early adulthood, entered at approximately 10 to 12 years of age and ending at 18 to 22 years of age".

Therefore, in this paper, adolescence is defined as the stage development of children from childhood to be adulthood (become mature).

\subsection{Academic Achievement}

Shamashuddin (2007) defines academic achievement as "the specified level of attainment of proficiency is academic work designed by test scores" (p.26). Kakkar (2016) describes academic achievement as an educational outcome which commonly assessed by exam or continuous assessment and shows that student, teacher, or institution has achieved the educational goals.

Zargar \& Ganai (2014) explain academic achievement as self-perception and selfevaluation of student's academic success, based on knowledge attitudes and skills projected by test scores and marks assigned by the teacher. Academic achievement is affected by the number of students in the class. The results suggest that the effects of a costly ten student reduction in class size are smaller than the benefit of moving one standard deviation up the teacher quality distribution, highlighting the importance of teacher effectiveness in the determination of school quality (Rivkin, Hanushek, \& Kain; 2005)

Based on the previous information, it can be said that academic achievement is an evaluation of learning based on students' knowledge and skill, assessed by exam or other assessment, and shows that students achieve the educational goals.

\section{Method}

This paper used the literature study method to gather information from relevant resources about adolescent behavior and mathematics learning engagement. This paper presents a thorough analysis of an alternative solution for managing adolescent students in mathematics class to promote learning engagement.

\section{Results and Discussion}

\subsection{Adolescents Attitudes toward School and Mathematics}

Adolescence, as a transition period from childhood to adulthood, brings many changes to child life. Especially started from early adolescence, students in this stage develop face many transitions from the school, rapid physical, social, and cognitive development. In the middle school environment, the emphasis on the rules, control, and disciplines may undermine student's positive orientation to school. Moreover, early adolescents also face social influence, where peers influence increases, and parental influence decreases (SimonsMorton \& Chen, 2009). In Berk's study (2012), three categories of adolescents and their problems were compared. The first category is students who have both problems in academic and mental. The second category consists of students who have only one area of the problem, and the third category consists of adolescents who can adapt well (have an excellent performance in both areas). Those students were in transition from middle school to high school when the research was conducted. The results showed that all of those adolescents had low academic achievement, but students from the third category keep 
having a good grade, followed by the second, respectively, and the least is students from the first category. The student from the first category showed a higher increase in being absent at school and behavioral problems outside school. For some adolescents, they showed a declining spiral in academic performance and engagement in school during the school transition from elementary to middle school.

Other studies found that girls' academic achievement is more affected negatively in adolescence (Berk, 2012). It happens because most girls will have significant changes in both their physical and mental development so that many adaptations needed to overcome the challenge of changes in this situation more than what happened to boys. Students who depressed from the decline of their academic performances according to the school transition show the decreasing pattern of self-esteem, motivation, and achievement. The issue of students' attitudes toward Mathematics also raised by Farooq and Shah (2008) in research. The sample was 685 grade 10 students with 379 male and 306 female students. The background of this study was about the gap differences between male and female students in their attitudes towards mathematics. Female students were more likely to have poor attitudes toward mathematics, and they do not want to take a higher level of math in high school. This attitude comes from the self-image of the peers too. This study aimed to find the difference between male and female students' attitudes towards mathematics, consisting of 4 variables, such as confidence about mathematics, the usefulness of mathematics, mathematics as a male domain, and perception about the teacher. The result of all those variables is the same; all of them show that there is no significant difference in the attitudes of male and female students towards mathematics in Pakistan. If this research link to what Berk said, even though gender difference did not affect the attitudes towards mathematics, the declining spiral in academic achievement cannot be avoided.

McDevitt \& Ormrod (2010) said that in adolescence stage development, adolescents begin to think beyond logic, and in an abstract way. The interests of young adolescents develop beyond family and their peer group. The changes in the environment will influence how adolescents think and behave. Their perception of school will bring some problems if it is not handled well. For adolescents, they thought about the importance of school is vital in this stage of development. Not only perception about the school, but adolescents' perception of a subject is also needed. In this case, the importance of mathematics subject. When adolescents think that mathematics is not necessary for their life, especially advance mathematics, it makes students do not want to take advanced mathematics in high school. It is proved by the research conducted by Harackiewicz, Rozek, Hulleman, \& Hyde (2012) shows that student interests in science and mathematics decrease mostly in high school. In the case of taking the course, the parent holds a vital role in motivating their kids to take mathematical subjects. In a mathematical lens, students were liking or interests might have occurred when students enjoy learning mathematics, value their mathematics learning and see its relevance in their own lives, see the connections between the mathematics they learn at school, and the one they use outside the school (Attard, 2012).

Van Brummelen (2008) states that through learning Mathematics, it is expected that students are able to understand the concepts of numbers, spaces, and the relationship of both. Strengthen their awareness that mathematics function can be used in daily life to solve problems. Experience mathematics as a developing science. According to Van Brummelen, students' attitudes toward mathematics should be positive if they meet those expectations.

\subsection{Impact of Student Behavioral Engagement}

As the most researched type of engagement, some studies usually define behavioral engagement as a key component supporting academic achievement. Research on engagement shows that behavioral engagement is still the strongest predictor for student achievement. Behavioral engagement also can be used to predict students' academic progress and growth more than emotional engagement (Harbour, Evanovich, Sweigart, \& Hughes, 2015).

Darensbourg \& Blake (2013) researched the roles of achievement values and behavioral engagement as predictors of achievement. One of the three research questions 
in the study asks about the role of behavioral engagement as a mediator for achievement values and academic achievement. It was a longitudinal study beginning in 2001 . The subjects of this research are 167 academically at-risk African American students (limited to those who are from a low socioeconomically disadvantaged background and low literacy) with their classroom teachers. Student behavioral engagement was assessed by using teacher reports. The results showed that the relationship between engagement and math achievement was significant in later elementary school, or it can be concluded as early adolescence. The effect of behavioral engagement on math achievement suggests that African American students who are behaviorally engaged within this domain persevere academically. The strength of this study is because it is longitudinal so that the data collected from the same subjects during the periodical time, and it followed the progress of the subjects as they were developing. One limitation of this study was the measurement of student behavioral engagement. Since it only used teacher-reported assessment, the perspective of behavioral engagement only comes from the teachers without considering the perspectives of the student. The use of self-reported may help in measuring complete student behavioral engagement.

In the Indonesian context, Triansa, Zendrato, dan Appulembang (2016) conducted research that aims to determine the effects of brainstorming on students' engagement in learning about probability. The method used in this research is the quasi-experimental with a non-equivalent control group. The data was collected through a questionnaire and analyzed by using non-parametric tests -- the Mann-Whitney U-test and the Wilcoxon Signed-Rank test with an alpha level of 0.05 . The results show that there was no significant difference on students' engagement before and after the experiment in the group taught without brainstorming. Besides, there was a significant difference in students' engagement before and after the experiment in the group taught using brainstorming. Also, there was no significant difference in students' engagement between the group taught with brainstorming and the group taught without brainstorming. The result of this research indicates that implementing brainstorming produces a positive effect on students' engagement in learning about probability in math classes.

Wang \& Fredricks (2014) studied changes of three types of school engagement related to changes in problem behaviors from 7th through 11th grades of 1272 youth from an ethnically and economically diverse county (consisted of 58\% African American, 36\% European American, 51\% females). The data were tested using the transactional model. The results showed that adolescents who had declines in behavioral and emotional engagement with school tended to have increased delinquency and substance use over time. The results also showed that there are bidirectional associations between behavioral and emotional engagement in school and youth problem behaviors over time. They concluded that lower behavioral engagement and greater problem behaviors predicted a greater likelihood of dropping out of school. That research shows that facilitating student behavioral engagement may increase the probability of positive schooling outcomes, such as academic success and school completion. Even though the problem of disengagement will not always become as extreme as drop out, it does not mean that this problem is trivial. Generally, student behavioral disengagement impacts how students learn during the lesson.

Student behavioral engagement contributes to meaningful learning. If students are behaviorally engaged, they will be involved during the class, and they have a sense of belonging to the class. This sense of belonging will make students experience the enjoyment of learning, recognize the meaning of learning, and not only come to the class just for getting by. It is the goal of a classroom as a learning community (Van Brummelen, 2009)

Furthermore, if students are not engaged in the classroom, they lose the opportunity to learn more. When students are behaviorally engaged, they will participate actively during the learning process. Research has proved that students will remember more if they are not only listening but also saying and doing what they learn because it will improve their memory about the learning, and it leads them to better academic achievement. When students get the meaning of the lesson, then it can be said that the learning objectives are reached. 
Another theory said that in the short-term, engagement could predict learning, grades, and behavior. In the long-term, engagement affects self-esteem. Engagement can be a protective factor against many different negative outcomes (Macklem, 2015). Self-esteem itself is important in shaping student personalities and affects how they value themselves. However, so far, there is no current research regarding self-esteem and behavioral engagement that shows a direct correlation between them.

\subsection{Influential Factors of Student Behavioral Engagement}

Before starting to study engagement more closely, educators need to know what influences student engagement. Since the three dimensions of student engagement are interrelated, the influential factors of one student engagement dimension can also influence the other two. Many types of research tried to find the factors influencing student engagement, but those researches did not mention all of them directly. The researches mostly tried to find the relationship for one or some variables into student engagement. Hobson (2015), in his study, showed that the important cause of student engagement problems in mathematics is the lack of connections between mathematics that they learn and mathematics in real life.

Wang \& Eccles (2013) mentioned two big factors of student engagement, which are a school, and individuals \& psychological factors. School characteristics include school structure support, provision of choice, teaching for relevance, and peer emotional support. Individual and psychological factors are divided into two big groups, individual characteristics (such as gender, race/ethnicity, and academic ability), and achievement motivation (academic self-concept and subjective task value). A similar opinion supported by Nako (2015) stated that student behavioral engagement caused by social contextual factors, such as students' perceptions of the teachers' attitudes and behaviors.

Seifert \& Sutton (2009) state that motivation is the energy that drives behavior direction and focuses. They divide motivation into two, intrinsic and extrinsic motivation. Intrinsic motivation comes from inside individual and extrinsic motivation affected by the factors outside the child. Motivation will influence emotional engagement, and then emotional engagement will influence cognitive and behavioral engagement since emotional engagement can provide energy for both kinds of engagement. Disengagement does not only happen in low achiever students but also a high achiever. High achiever students with low engagement usually caused by their thinking that school is easy (Macklem, 2015). Wang \& Eccles said that academic ability influences student engagement, but if educators look indepth, what is more, important is motivation. If a student has good academic ability, but he does not have the motivation, he can have low engagement in school or vice versa. Motivation drives the thoughts of how and why students should learn.

Motivation itself influenced by some factors. The major perspective on motivation is based on self-efficacy theory, extended by self-determination theory (Seifert \& Sutton, 2009). According to the self-efficacy theory, motivation is based on a person's belief that he/he is able to master a task. High self-efficacy students will have persistence and resilience when facing failure. Self-determination theory is based on the idea that everyone has three basic needs; they are autonomy, competence, and relatedness. Based on this theory, students will be more intrinsically motivated if these needs are met.

Family is the most influential environment of growth since the first place where a child grows is in his family. Parents emotional support for their children are proven to be positively related to their children's behavioral engagement in school (Virtanen, Lerkkanen, Poikkeus, \& Kuorelahti, 2014). The more parents give support, and the more engaged their children will be. Awareness for parents is very critical for adolescents' academic success. Afriyanti \& Kusdiyati (2015), in their research, showed that student engagement is strongly related to peers and parents influence, students with great influence from both parties tend to be highly engaged, and students with low engagement mostly come from the low level of parents' support family.

Teachers have an important role in the classroom. The various roles of a teacher make him/her become the center of attention in the classroom. Moreover, teachers are the one 
who has the authority to manage the classroom itself. With authority given, so that what and how he/she does will have a huge impact on the learning process. Teachers can create an optimal learning environment in the classroom, which is believed as one factor of student engagement. Research by Vyanti, Hidayat \& Appulembang (2016) supports that the role of teachers influences student behavioral engagement. The sample of the experiment group consisted of 17 students, and the control group consisted of 18 students from grade 12 . This research used an experimental research method with Pretest-Posttest Control Group Design. The data collection showed that the group which is given positive reinforcement by the teacher had a significant increase in their behavioral engagement in Mathematics class. Therefore, student-teacher and children-parents relationships are significant to increase student behavioral engagement. Kaensige \& Yohansa (2018) researched teaching using the Class123 application. The research showed that the use of Class123 could increase students' behavioral engagement.

A study shows that peer support is important for influencing student behavioral engagement (Simons-Morton \& Chen, 2009). This study shows that problem-behaving friends can support students to have good engagement in school.

Another study from Virtanen, Lerkkanen, Poikkeus, \& Kuorelahti (2014) investigated the associations between student's behavioral engagement, teacher, family, and peer emotional support, and school truancy. The data collected from 821 Finnish junior high school students. The result showed that teacher and family support were positively related to student behavioral engagement and negatively related to truancy since they are likely to conform to the expectations of teachers and parents. Otherwise, they state that peer emotional support was not associated with student behavioral engagement. If the peers have neutral attitudes, meaning that the peers are not extremely ignorant to school, it does not assure that this student will engage in the classroom. In other words, this student still can be disengaged. This study also states that negative peer emotional support can make students discourage to engage.

In the same research, Virtanen, Lerkkanen, Poikkeus, \& Kuorelahti (2014), using the data measured by structural equation modeling, peers' neutral attitudes in engagement may not affect disengagement, but it does not explain what if the peer emotional support is positive. In the statistical result, it is stated that peer emotional support is not giving a significant impact on student behavioral engagement. However, in the discussion part, it is stated that negative emotional support can discourage the student from being engaged, and if the peers have neutral attitudes on school truancy, it cannot prevent the student from avoiding truant. Hence, peers emotional support has an impact on student behavioral engagement.

Based on the developmental theory, peers are prominent in adolescence. Student development will be influenced by who and how their peers are. "Students who care for each other and perceive that they are in a caring environment are motivated to engage cognitively and behaviorally" (Davis, Summers, \& Miller, 2012, p.26). Perhaps, peer support does not have a direct link into student behavioral engagement, but the favorable environment to learn in the classroom, created by peers, will help students to conform and engage in the teaching and learning process. Therefore, it is still essential to look at peers as influential factors of student engagement because, without peers' supports in making an optimal learning environment, students cannot be more behaviorally engaged during the learning process. In this case, peer emotional support should be positive, not neutral, or even harmful.

Parent support is more influencing than peers support, but teacher support is more important than parents' support (Virtanen, Lerkkanen, Poikkeus, \& Kuorelahti, 2014). Motivation is an essential factor that can drive student behavior. The intrinsic motivation as the most durable type of motivation can help students to overcome the other influential factors of student disengagement, such as the individual characteristics (like race/ethnicity or academic ability, etc.). The teacher can help students to raise their motivation so that they can be more behaviorally engaged. However, focusing only on motivation is often not adequate to maintain a high level of student behavioral engagement (Attard, 2012). 
Therefore, the other influential factors need to be improved along with the motivation to get the optimal student engagement.

In conclusion, many factors can influence student engagement in the classroom. By understanding the factors, it is hoped that the teacher can suppress the risk of behavioral disengagement in school.

\subsection{Obstacles in Promoting Student Behavioral Engagement}

After knowing the influential factors of student behavioral engagement, educators may look at them and trying to promote student behavioral engagement. As the keys to promote student behavioral engagement, those factors also bring up challenges.

First, the motivation, even though it is believed to be the most influential factor leading to engagement, enhancing student motivation, is not an easy step to take by educators or parents. The role of parents and teachers in motivating students to learn is limited to extrinsic motivation, which is known to be weaker than intrinsic motivation.

The second obstacle comes from the aspects of the teachers. One of the challenging factors to promote student behavioral engagement is the teacher's beliefs about student engagement. Teacher's beliefs here include causes, strength, and malleability of student behavioral engagement (Macklem, 2015). Teacher beliefs also determine the instructional effort in the classroom to promote positive student engagement. If teachers think that student behavioral engagement is malleable or changeable, they will have an optimistic opinion about promoting student behavioral engagement in their class. If teachers believe that some factors cause student behavioral engagement, and they understand the importance of student behavioral engagement, they will give more effort in their teaching to promote it. Skilling (2014) states that teachers who believe in the importance of engaging students in mathematics use practices regularly that promote student engagement by meeting their motivational needs for competency and self-efficacy.

Furthermore, it was started by Ivan Pavlov in his classical conditioning of contiguity theory (O'Donnell, Reeve, \& Smith, 2007). This theory stated that learning is the result of events occurring at the same time. Pavlov used a dog as the subject of the experiment. The discovery then applied in the classroom, and it was shown that humans showed the same response as a dog when a stimulus and a response are paired. Learning theory that depends on contiguity as the mechanism by which learning occurs, the learner is passive. Furthermore, the theory of behavior assumes a more active learner called Operant learning. After Pavlov, Skinner developed the theory of behaviorism. "Skinner's approach was to try to identify relationships between elements of the environment that would predict behavior. His approach has often been described as a black box theory with information from the environment going into the individual who then behaves" (2007, p. 210).

Parents have a big responsibility in finding quality time with the children is another challenge or obstacle in promoting student engagement. Not all parents find difficulties in sparing time for their kids, but some parents are too busy with their jobs and give the responsibilities of taking care of their children to baby sitters or household assistant. The fewer amount of quality time makes parents do not have enough time to control or supervise their children's learning. Communication between parents and children can decrease along with the process of growth, especially in adolescence. Some other parents are ignorant to take part in their kids' academic grades. Parents play an important role in collaborating with the teacher to make an optimal learning environment at home.

The next challenges come from peers. Peers is a community where children can find friends who are at the same age as them and consist of people from various background and parental styles. Background and parental styles affect how the character of the children is built. Since the relation to peers increases during adolescence, the character of peers can also influence children. Peers are esteemed, but because peers come from various backgrounds, it is challenging to ensure that peers can give emotional support for students. 


\subsection{Promoting Student Behavioral Engagement}

From all the factors explained previously, motivation is the most influential behavioral factor in enhancing student engagement. Through motivation, students will be encouraged to be engaged in the classroom.

Many research and literature explain and offer various ways to increase student engagement, such as active learning, critical thinking, cooperative learning, inquiry-based learning, etc. It is impossible to make $100 \%$ of students engage in the classroom. Several challenges described also makes it harder to solve the problems of disengagement. Gazalie \& Hidayat (2015) showed in their research that useful feedback improves students' emotional and behavioral engagement.

As the principle of the curriculum design to increase student behavioral engagement, it is essential to develop teaching styles, make a challenging learning environment for all students, and make it enjoyable (Warwick, 2008). Also, Warwick states that strengthening self-efficacy can also strengthen student engagement. This statement makes sense because if students have an excellent self-efficacy in math, they will be more confident to be active in the classroom. To make this real, then the focus should be on how to reduce math anxiety and enhance self-efficacy in the class. Self-efficacy also includes how the child looks at the extent of his ability to do the math. Teachers need to encourage the class to help the student increase their self-efficacy, and then it can also increase their motivation to learn and become engaged.

Another consideration comes from using active learning or cooperative learning. The question is whether to make children work in groups is useful. If it is not sufficient, it would just be a waste of time. Students in the adolescence period tend to have cliques. In using cooperative learning, teachers usually divide children into groups randomly for some reason. If the students get to the group that they are not interested in and are forced to work in a group, they will not feel comfortable so that they do not have the willingness to work and do not get the meaning of learning in the end. Thus, the learning objectives also can not be reached. On the contrary, if the teacher lets students choose their partners by themselves, it can also cause conflict among students. In the case of making a group, teachers should be conscientious in order to maintain a pleasant classroom environment.

Cappela, Kim, Neal, \& Jackson (2013) explain that the ideas from social capital theory and social process research inside and outside the classroom may be relevant to explain when students are involved in the classroom academic community and have academic or social support from peers, the classroom activities may be more available. Imandoust (2011, p.52) explained that "social capital refers to the networks of social relations that may provide individuals and groups with access to resources and supports, interconnected and inclusive setting can create a space to engage in the activities." Based on that perception, the intervention that enhances integrated or cooperative communities improve student engagement. Therefore, focusing on peer resources and structures within classrooms can build a deeper understanding of the learning process that predicts student behavioral engagement. By these steps, it is expected that student behavioral engagement develop started from the classroom and makes it useful into their community, such as being responsible for accomplishing the task given in their profession.

\section{Conclusion and Suggestion}

Based on the previous discussion, it can be concluded that students' attitudes toward school and mathematics are mostly positive. However, it decreases mostly in high school. Students who are not behaviorally engaged in the classroom lose the opportunity to learn more and get the meaning of the learning. For the short term, student behavioral engagement can predict academic achievement, and for the long term, it can affect students' self-esteem.

The most influential factors of behavioral engagement are motivation, the role of teachers and parents, and peer support. Obstacles in promoting student behavioral engagement based on the influential factors are the limitation of extrinsic motivation, 
teachers' beliefs about student behavioral engagement, and parental styles in educating children.

\section{References}

Afriyanti, F., \& Kusdiyati, S. 2015. Studi deskriprif school engagement siswa kelas x, xi, dan xii ips sma mutiara 2 bandung. Prosiding Psikologi Seminar Penelitian Sivitas Akademika (pp 460-467). Bandung: Universitas Islam Bandung.

Ashari, H. 30 Desember 2014. Badan pendidikan dan pelatihan keuangan kementrian keuangan. Diambil dari bppk kemenkeu: http://www.bppk.kemenkeu.go.id/publikasi/artikel/147-artikel-anggaran-danperbendaharaan/20310-anggaran-pendidikan-20-,-apakah-sudah-dialokasikan

Attard, C. 2012. Engagement with Mathematics: What Does It Mean and What Does It Look Like. Australian Primary Mathematics Classroom, 17(1): 9-13. Retrieved from: https://files.eric.ed.gov/fulltext/EJ978128.pdf

Barkatsas, A. (Tasos), Kasimatis, K. and Gialamas, V. (2009) 'Learning secondary mathematics with technology: Exploring the complex interrelationship between students' attitudes, engagement, gender and achievement', Computers and Education. Elsevier Ltd, 52(3), pp. 562-570. doi: 10.1016/j.compedu.2008.11.001.

Berk, L. 2012. Development through the lifespan: Dari prenatal sampai masa remaja, transisi menjelang dewasa (Volume 1) (5 $5^{\text {th }}$ Ed.). Yogyakarta, Indonesia: Pustaka Pelajar.

Cappela, E., Kim, H., Neal, J., \& Jackson, D. 2013. Classroom Peer Relationships and Behavioral Engagement in Elementary School: The Role of Social Network Equity. Am J Community Psychol, 52(1): 367-379. doi: https://dx.doi.org/10.1007/s10464-0139603-5

Clark, N. 4 April 2014. World Education News and Review. Diambil dari wenr: http://wenr.wes.org/2014/04/education-in-indonesia

Conner, T. 2016. Relationships: The Key to Student Engagement. International Journal of Education and Learning, 5(1): 13-22. doi: https://dx.doi.org/10.14257/ijel.2016.5.1.02

Darensbourg, A., \& Blake, J. 2013. Predictors of Achievement in African American Students at Risk for Academic Failure: The Roles of Achievement Values and Behavioral Engagement. Psychology in the Schools, 50(10): 1044-1059. doi: https://dx.doi.org/10.1002/pits.21730

Davis, H., Summers, J., \& Miller, L. 2012. An Interpersonal Approach to Classroom Management: Strategies for Improving Student Engagement. California, CA: Corwin.

DePree, J. (1998). Small-group instruction: Impact on basic algebra students. Journal of Developmental Education, 22(1), 2.2 Retrieved from https://search.proquest.com/openview/773ee8ee4307ee383fe83f160a30bb7d/1 ?cbl=2 030483\&pq-origsite $=$ gscholar

Farooq, M., \& Shah, S. Z. U. 2008. Students' Attitude Towards Mathematics. Pakistan Economic and Social Review, 46(1): 75-83. Diambil dari http://pu.edu.pk/images/journal/pesr/PDF-

FILES/5\%20FAROOQ\%20Students\%20Attitude.pdf

Fredricks, J. A., Blumenfeld, P. C., \& Paris, A. H. (2004). School engagement: Potential of the concept, state of the evidence. Review of educational research, 74(1), 59-109. https://doi.org/10.3102\%2F00346543074001059

Frenzel, A. C., Goetz, T., Pekrun, R., \& Watt, H. M. (2010). Development of mathematics interest in adolescence: Influences of gender, family, and school context. Journal of Research on Adolescence, 20(2), 507-537. https://doi.org/10.1111/j.15327795.2010.00645.x

Gazalie, D. D. P., \& Hidayat, D. 2015. The Use of Effective Feedback to Improve Students' Emotional and Behavioral Engagement. Polyglot: Jurnal IImiah (11)4: 32 - 48. Diambil dari http://repository.uph.edu/2405/1/poly-11-04-2015-the_use_\%20of_effective.pdf

Goldin, G. A., Epstein, Y. M., Schorr, R. Y., \& Warner, L. B. (2011). Beliefs and engagement structures: Behind the affective dimension of mathematical learning. ZDM, 43(4), 547. https://doi.org/10.1007/s11858-011-0348-z 
Harackiewicz, J., Rozek, C., Hulleman, C., \& Hyde, J. 2012. Helping parents to motivate adolescents in mathematics and science: An experimental test of a utility-value intervention. Psychological Science, 23(8): 899-906. doi: https://dx.doi.org/10.1177/0956797611435530

Harbour, K., Evanovich, L., Sweigart, C., \& Hughes, L. 2015. A Brief Review of Effective Teaching Practices That Maximize Student Engagement. Preventing School Failure, 59(1): 5-13. doi: https://dx.doi.org/10.1080/1045988X.2014.919136

Hart, S., Stewart, K., \& Jimerson, S. 2011. The Student Engagement in Schools Questionnaire (SESQ) and the Teacher Engagement Report Form-New (TERF-N): Examining the Preliminary Evidence. Contemporary School Psychology, 15: 67-79. Diambil dari https://eric.ed.gov/?id=EJ934707

Hobson, P. 2015. Am i engaged with mathematics? A child's perspective!. Transformations, 1: 74-86. Diambil dari https://pdfs.semanticscholar.org/4cc1/c5b0e735e405855443d56f0b9711ce54c844.pdf

Imandoust, S. (2011). Relationship between education and social capital. International Journal of Humanities and Social Science, 1(12): 52-57. Diambil dari http://www.ijhssnet.com/journals/Vol_1_No_12_September_2011/8.pdf

Kaensige, A.L. \& Yohansa, M. 2018. Penggunaan aplikasi Class123 sebagai upaya meningkatkan keterlibatan perilaku siswa kelas XII IPA di suatu SMA di Tangerang. JOHME: Journal of Holistic Mathematics Education 2(1): 57 - 70 . doi: https://doi.org/10.19166/johme.v2i1.940

Ketonen, E. E. and Hotulainen, R. (2019) 'Development of low-stakes mathematics and literacy test scores during lower secondary school - A multilevel pattern-centered analysis of student and classroom differences', Contemporary Educational Psychology. Elsevier, 59(July), p. 101793. doi: 10.1016/j.cedpsych.2019.101793.

Macklem, G. 2015. Boredom in the classroom: Addressing student motivation, selfregulation, and engagement in learning. Switzerland: Springer International Publishing.

McDevitt, T., \& Ormrod, J. 2010. Child development and education (4 ${ }^{\text {th }}$ Ed.). New Jersey, $\mathrm{NJ}$ : Pearson Education.

Kakkar, N. 2016. A study of academic achievement relation to home environment of secondary school students. The international Journal of Indian Psychology, 4(1): 3040. Diambil dari http://oaji.net/articles/2016/1201-1455865971.pdf

Nako, N. 2015. Factors influencing academic engagement and achievement : Exploration of impact of parentification and poverty in adolescents' student-teacher relationships. Disertasi dipublikasikan. Western Michigan University, Graduate College. Diambil dari https://scholarworks.wmich.edu/dissertations/532/

O'Donnell, A., Reeve, J., \& Smith, J.K. 2007. Educational psychology: Reflection for action. New Jersey, NJ: John Wiley \& Sons.

Rice, F., \& Dolgin, K. 2008. The adolescent: Development, relationships, and culture (Twelfth ed.). Boston, BO: Pearson Education.

Rivkin, S. G., Hanushek, E. A., \& Kain, J. F. (2005). Teachers, schools, and academic achievement. Econometrica, 73(2), 417-458. https://doi.org/10.1111/j.14680262.2005.00584.x

Santrock, J. 2007. Child development (1 $11^{\text {th }}$ Ed.). New York, NY: McGraw-Hill.

Seifert, K., \& Sutton, R. 2009. Educational psychology (2 ${ }^{\text {nd }}$ Ed.). Zurich, Switzerland: Global Project.

Shamashuddin, S. 2007. Values and academic achievement. (V. Reddy, \& D. Rao, Eds.) New Delhi, India: Discovery Publishing House.

Shernoff, D. 2013. Optimal learning environments to promote student engagement. New York, NY: Springer.

Simons-Morton, B., \& Chen, R. 2009. Peer and parent influences on school engagement among early adolescents. Youth \& Society, 41(1), 3-25. doi: https://dx.doi.org/10.1177/0044118X09334861 
Skilling, K. 2014. Teacher practices: How they promote or hinder Student engagement in mathematics. Proceedings of the $37^{\text {th }}$ annual conference of the Mathematics Education Research Group of Australasia (pp. 589-596). Sydney, Australia: MERGA.

Triansa, E. A., Zendrato, J., \& Appulembang, O. D. (2016). The effect of brainstorming implementation on students' engagement in learning about probability in math classes in grade XI IPA at SMA ABC Cikarang. Polyglot: Jurnal IImiah, 12(1), 20-30. doi: http://dx.doi.org/10.19166/pji.v1i1.380

Van Brummelen, H. 2008. Batu loncatan kurikulum, berdasarkan alkitab. Jakarta, Indonesia: Universitas Pelita Harapan.

Van Brummelen, H. (2009). Walking with God in the classroom: Christian approaches to teaching and learning. Colorado, CO: Purposeful Design Publications.

Virtanen, T., Lerkkanen, M., Poikkeus, A., \& Kuorelahti, M. 2014. Student behavioral engagement as a mediator between teacher, family, and peer support and school truancy. Learning and Individual Differences, 36: 201-206. doi: https://doi.org/10.1016/j.lindif.2014.09.001

Vyanti, V., Hidayat, D. \& Appulembang, O.D. 2016. Pengaruh penguatan positif terhadap keterlibatan perilaku siswa dalam kelas matematika. Prosiding Seminar Pendidikan Matematika. Universitas Negeri Malang. Diambil dari http://pasca.um.ac.id/wpcontent/uploads/2016/09/ProsidingPendidikanMatematikaPascaUM2016.pdf

Wang, M., \& Eccles, J. 2013. School context, achievement motivation, and academic engagement: A longitudinal study of school engagement using a multidimensional perspective. Learning and Instruction, 28: 12-23. doi: https://dx.doi.org/10.1016/j.learninstruc.2013.04.002

Wang, M., \& Fredricks, J. 2014. The reciprocal links between school engagement, youth problem behaviors, and school dropout during adolescence. Child Development 85(2): 722-737. doi: https://doi.org/10.1111/cdev.12138

Warwick, J. 2008. Mathematical self-efficacy and student engagement in the mathematics classroom. MSOR Connections 8(3): 31-37. doi: https://doi.org/10.11120/msor.2008.08030031

White, J. W. (2011). Resistance to classroom participation: Minority students, academic discourse, cultural conflicts, and issues of representation in whole class discussions. Journal of Language, Identity \& Education, 10(4), 250-265. https://doi.org/10.1080/15348458.2011.598128

Zargar, S. S., \& Ganai, M. Y. 2014. Self-concept, learning syles, study habits and academic achievement of adolescents in kashmir: A study on psychological variables and academic achievement of adolescents in kashmir. Hamburg, Germany: Anchor Academic Publishing.

Zhu, X. et al. (2019) 'The developmental trajectory of behavioral school engagement and its reciprocal relations with subjective well-being in school among Chinese elementary school students', Children and Youth Services Review. Elsevier, 99(February), pp. 286-295. doi: 10.1016/j.childyouth.2019.01.024. 